mother to young and the catabolism of immunoglobulins. Lancet 2:1087-1093. 1966.

5. DROEGE, W. The antigen-inexperienced thymic suppressor cells: A class of lymphocytes in the young chicken thymus that inhibits antibody production and cell mediated immune responses. Eur. J. Immunol. 6:279-287. 1976.

6. FAHEY, J.L. and E.M. McKelVEY. Quantitative determination of serum immunoglobulins in antibody-agar plates. $J$. Immunol. 94:84-90. 1965.

7. Glick, B., T.S. Chang, and R.G. JaAP. The bursa of Fabricius and antibody production. Poultry Sci. 35:224-225. 1956.

8. Higgins, D.A. and B. W. Calnek. Fowl immunoglobulins: Quantitation in birds genetically resistant and susceptible to Marek's disease. Infection and Immunol. 12:360-363. 1975.

9. IVANYI, J. and R. Morris. Immunodeficiency in the chicken: An immunological study of infectious bursal disease. Clin. Exp. Immunol. 23:154-165. 1976.

\section{Inheritance of resistance to watermelon mosaic virus 1 in Cucumis metuliferus}

\section{R. Provvidenti and R. W. Robinson}

$\mathrm{R}^{\mathrm{E}}$ ECENTLY, Provvidenti and Robinson ${ }^{5}$ reported that two accessions (P.I. 202681 and P.I. 292190) of Cucumis metuliferus (Naud.) Mey., were highly resistant to watermelon mosaic virus $1(\mathrm{WMV}-1)$ and hypersensitive resistant to squash mosaic virus (SqMV). They also reported that two other accessions of this species were susceptible to the same viruses. This paper reports the inheritance of resistance to WMV-1 in P.I. 292190.

\section{Materials and Methods}

The genetic material used in this investigation was derived from crosses and backcrosses of P.I. 292190 with Acc. 2459, a susceptible line. Seeds of P.I. 292190 were obtained from the U.S. Department of Agriculture, Northeast Regional Plant Introduction Station, Geneva, New York; those of Acc. 2459 were received from the Hortus Botanicus, Leyden, The Netherlands. Uniform germination was achieved by placing seeds on moist blotter paper in plastic dishes that were incubated for 3-5 days at $5^{\circ} \mathrm{C}$ and then kept at $30^{\circ} \mathrm{C}$. Inoculum was prepared by triturating leaves of WMV-1-infected Cucurbita pepo L., 'Seneca Zucchini', with $0.05 \mathrm{M} \mathrm{K}_{2} \mathrm{HPO}_{4}$ at $\mathrm{pH}$ 7.0. Plants of both parents and their progenies were mechanically inoculated at the cotyledonary stage and reinoculated when the fruit and second leaves were fully expanded. These two routine inoculations were sufficient to assure infection of all susceptible plants. The virus, isolate NY69-49, had been used in a previous study ${ }^{5}$. Recovery tests for virus infection were made from all plants that had remained symtomless, using Seneca

The authors are senior research associate, and associate professor, respectively, New York State Agricultural Experiment Station, Cornell University, Geneva, New York 14456.
10. LunNey, J. and G. AshwEl.l. A hepatic receptor of avian origin capable of binding specifically modified glycoproteins. Proc. Natl. Acad. Sci. 73:341-343. 1976.

11. Luster, M.I., G.A. Leslie, and R.K. Cole. Selective IgA deficiency in chickens with spontaneous autoimmune thyroiditis. Nature 263:331. 1976.

12. Sanders, B.G. and K. Kline. Expression of serum proteins in the developing chick embryo. Comp. Biochem. Physiol. in press. 1977.

13. ScheidegGer, J.J. Une micro-methode de l'immunoelectropherese. Int. Arch. All. App. Immunol. 7:103-110. 1955.

14. Wochner, R.D. G. Drews, W. STrober, and T.A. WALDMANN. Accelerated breakdown of immunoglobulin $G$ (IgG) in myotonic dystrophy: A hereditary error of immunoglobulin catabolism. J. Clin. Invest. 45:321-329. 1966.

15. WoCHNER, R.D. Hypercatabolism of normal IgG; an unexplained immunoglobulin abnormality in the connective tissue diseases. J. Clin. Invest. 49:454-464. 1970.

Zucchini squash as indicator host. This work was conducted in an insect-free greenhouse that was maintained at $27^{\circ} \mathrm{C}$

\section{Results and Discussion}

Plants of P.I. 292190 inoculated with WMV-1 did not become infected, whereas those of Acc. 2459 reacted with severe systemic symptoms. Plants were stunted with leaves reduced in size, showing a light green mottle and distortion. The genetic basis for WMV-1 resistance in C. metuliferus, P.I. 292190, is detailed in Table I. All the $F_{1}$ plants were resistant, and the virus was not recovered from inoculated or noninoculated leaves. In $F_{2}$ populations, segregation was 3 resistant plants to 1 susceptible. The backcrosses to the resistant parent were all resistant, whereas $F_{1}$ backcrosses to the susceptible parent segregated in a $1: 1$ ratio. Thus, the high level of resistance to WMV-1 in plants of P.I. 292190 was governed by a single dominant factor. For this gene, the symbol Wmv (watermelon mosaic virus) is proposed.

Cucumis metuliferus is a potential source of resistance to WMV-1, SqMV ${ }^{5}$ and to the root-knot nematode ${ }^{3}$, Meloidogyne incognita acrita [(Kofoid \& White) Chitwood]. This feral cucurbit speies, a native of southern

Table I. Response of Cucumis metuliferus to watermelon mosaic virus 1

\begin{tabular}{|c|c|c|c|c|}
\hline & \multicolumn{2}{|c|}{ No. plants } & \multirow{2}{*}{$\begin{array}{l}\text { Ex- } \\
\text { pected } \\
\text { ratio }\end{array}$} & \multirow{2}{*}{$\begin{array}{l}\text { Good- } \\
\text { ness- } \\
\text { of-fit } \\
(P)\end{array}$} \\
\hline & $\begin{array}{c}\text { Resist- } \\
\text { ant }\end{array}$ & $\begin{array}{l}\text { Suscep- } \\
\text { tible }\end{array}$ & & \\
\hline P.I. 292190 & 80 & 0 & & \\
\hline $\begin{array}{l}\text { Acc. } 2459 \\
\text { Acc } 2459 \times P\end{array}$ & 0 & 75 & & \\
\hline $\begin{array}{l}292190) F_{1} \\
\text { (Acc. } 2459 \times \text { P.I. }\end{array}$ & 58 & 0 & & \\
\hline $\begin{array}{l}292190) \mathrm{F}_{2} \\
\text { (Acc. } 2459 \times \text { P.I. } \\
292190) \mathrm{F}_{1} \times \text { P.I. }\end{array}$ & 182 & 55 & $3: 1$ & 0.53 \\
\hline $\begin{array}{l}292190 \\
\text { (Acc. } 2459 \times \text { P.I. }\end{array}$ & 74 & 0 & & \\
\hline $\begin{array}{l}292190) \mathrm{F}_{1} \times \text { Acc. } \\
2459\end{array}$ & 86 & 79 & $1: 1$ & 0.65 \\
\hline
\end{tabular}


Africa, is commonly known as the 'horned cucumber' or 'jelly melon' for its prominent fleshy spines and for the jelly-like sacs that individually envelop hairy seeds*. Genetically, with 12 pairs of chromosomes ${ }^{6}$, it is closer to muskmelon than cucumber, but difficulties have been encountered in crossing it with $C$. melo L., and other Cucumis species ${ }^{2,5}$. Although preliminary attempts using immunosuppressant agents ${ }^{1}$ to overcome barriers of incompatibility have been encouraging, more research is needed in this area. In C. melo, a source of resistance to WMV-1 has been available for several years ${ }^{7}$, but the inheritance of this resistance has not been reported. Crosses between WMV-1-resistant lines of $C$. metuliferus and $C$. melo, if they should become feasible, will determine whether factors for resistance in these two species are different.

\section{Summary}

In Cucumis metuliferus (Naud.) Mey., P.I. 292190, a feral species from southern Africa, commonly known as

\section{The demise of Lysenko}

\section{BarRy Mendel Cohen}

I

N HIS public life Trofim Denisovich Lysenko had the proverbial nine lives of the cat, but as with all mortal men-even those once exalted by Stalin-death claimed his only physical life on November 20, 1976 ${ }^{1}$. Lysenko was 78 years of age, and had lived a long and malevolent life.

And yet it had not begun in that fashion. As early as February and March, 1933, the readers of the Journal of Heredity learned that a talented young agronomist, Lysenko, had developed the technique now known as vernalization. The authors, H.H. McKinney and W.J. Sando were very impressed with Lysenko's temperature studies, but felt that he had underestimated the importance of light as a factor that determines the germination of plants. This was controversy, but well within the bounds of science.

Lysenko, unfortunately, was not satisfied with authentic scientific debate. By 1935 he had tied his theory of phasic development to Marx's theory of the development of society. He had convinced the Soviet government to embark on a gigantic and largely unsuccessful application of vernalization to agriculture. And he began to make personal attacks on the leaders of Soviet biology, for example, Nikolai Ivanovich Vavilov. We became aware of the public attacks in the addresses made by Lysenko to the Soviet Genetics Congresses of 1936 and 1939. In private, the attacks were more severe. It is a sad event to confirm what has long been suspected, namely that Lysenko used the Soviet secret police to eliminate his scientific opponents ${ }^{2}$.

The authors address is 3527 Granada, Dallas, Texas 75205.

1. The New York Times, November 24, 1976, p. 36.

2. Zhores Medvedev, Khrushchev: The Years in Power(New York, 1976), p. 22. the 'horned cucumber' or 'jelly melon', a single completely dominant gene, $W m v$, governs a high level of resistance to watermelon mosaic virus 1 .

\section{Literature Cited}

1. Bates, L.S., A.V. Campos, R.R. Rodriguez, and R.G. ANDERSON. Progress toward novel cereal grains. Cereal Sci. Today 19:283-286. 1974.

2. Deakin, J.R., G.W. BohN, and T.W. Whitaker. Interspecific hybridization in Cucumis. Econ. Bot. 25:195-211. 1971.

3. Fassuliotis, G. Species of Cucumis resistant to the rootknot nematode, Meloidogyne incognita acrita. Plant Dis. Reptr. 51:720-723. 1967.

4. Meeuse, A.D.J. The Cucurbitaceae of South Africa. Bothalia 8:1-11. 1962.

5. Provvidenti, R. and R.W. Robinson. Resistance to squash mosaic virus and watermelon mosaic virus 1 in Cucumis metuliferus. Plant Dis. Reptr. 58:735-738. 1974.

6. Shimotsuma, M. Chromosome studies of some Cucumis species. Seiken Zihô. 17:11-16. 1965.

7. WEB B, R.E. Cantaloup breeding line B66-5: Highly resistant to watermelon mosaic virus 1. HortScience 2:58-59. 1967.

By 1948, Lysenko, with Stalin's aid, was able to enforce his views on the Soviet biological community. With Stalin's death in 1953, Lysenko lost absolute power, but continued to exercise considerable influence with the support of Khrushchev.

Even this influence came to an end with Khrushchev's fall in October 1964. By February 1965, Lysenko had been removed as director of the Institute of Genetics, a post he had assumed in 1940 upon the arrest of Vavilov ${ }^{3}$. Lysenko's mouthpiece, Agrobiology, came to an end with the December issue of 1965. In November 1965, Lysenko's conduct of the Gorki-Lenin Farm was held up to severe public criticism, but he was allowed to retain his position there until his death ${ }^{4}$. The popular journal Oktybr' continued to publish pro-Lysenko articles, but this ended in 1966 . In that year all instruction in genetics came to a halt while teachers and instructors relearned the tenets of "Mendelism-Morganism',

Officially the Soviets have never truly faced the reality of Lysenkoism. Zhores Medvedev's candid book of 1969, The Rise and Fall of T.D. Lysenko, has not been published in the Soviet Union and the Russians must rely on N.P. Dubinin's memoir of 1973, Perpetual Motion, for a "things-weren't-really-as-bad-as-theylooked' account of Lysenkoism.

Lysenko leaves a bitter memory of the brutal introduction of politics into science. But one part of Lysenko's legacy is a surprise, namely the general movement of Soviet dissent. As a coiled spring subjected to everincreasing pressure builds ever-increasing resistance, so with the Soviet effort to impose ideology on science. It was at the most absurd point, the attack on genetics, that resistance to Stalinism began to develop, soon becoming an important national force, perhaps a force that will one day carry the Soviet Union to real freedom.

3. The New York Times, February 5, 1965, p. 3.

4. Vestnik Akademii Nauk(November, 1965). 